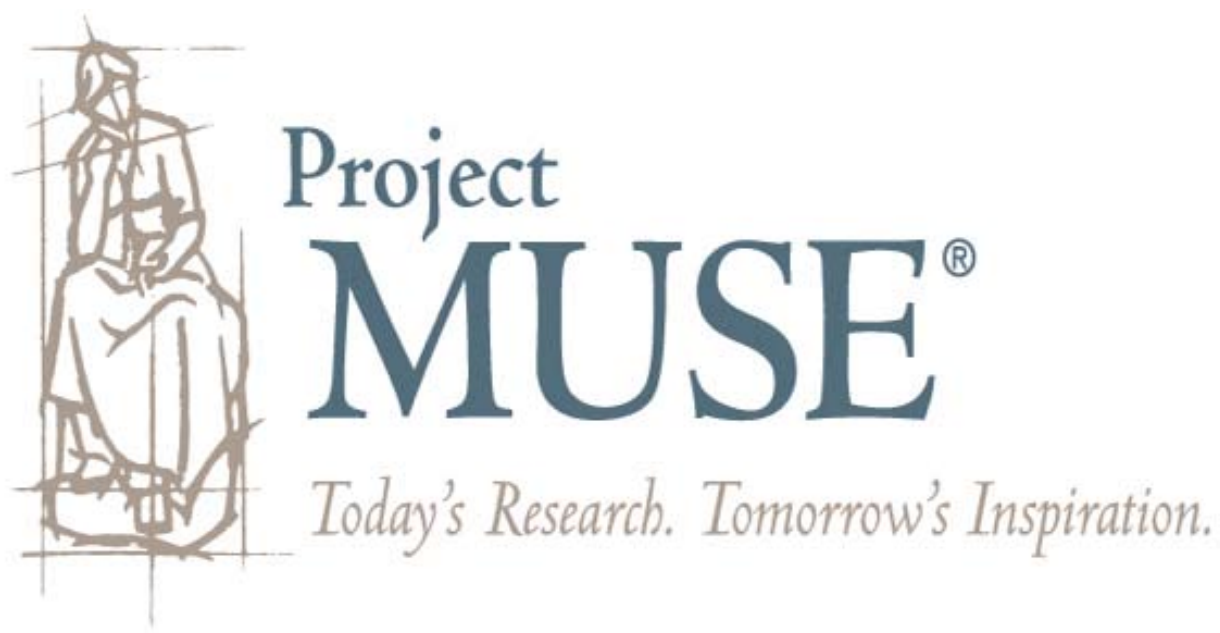




\title{
On the Modern and the Nonmodern in Deliberative Environmental Democracy
}

\author{
Kersty Hobson
}

\section{Introduction}

Modernity comes in as many versions as there are thinkers or journalists, yet all its definitions point, in one way or another, to the passage of time. The adjective "modern" designates a new regime, an acceleration, a rupture, a revolution in time. When the word "modern," "modernization," or "modernity" appears, we are defining, by contrast, an archaic and stable past. Furthermore, the word is always being thrown into the middle of a fight, in a quarrel where there are winners and losers, Ancients and Moderns. ${ }^{1}$

So claimed the French philosopher Bruno Latour in his thesis on how, when, and with what effect the idea of the Modern came about as a geographically distinct group of peoples and a set of individual characteristics, qualities and knowledge. This article opens with Latour's words as they succinctly encapsulate the ideas that are brought below into conversation with deliberative democratic theory and practice: a body of work that has in part laid the foundations for the recent "deliberative turn" within environmental politics. This article takes up Latour's above claims and concerns about who the Modern deliberating subject is, asking why s/he stands as so central to this deliberative turn and what happens if others join in, such as Latour's Ancients?

Such questions are more pressing than their seemingly abstruse nature suggests. They are in fact central to recent calls for empirical deliberative research to pay attention to seemingly "nonmodern" places, to broaden deliberative democracy's geographical ambit, and thus enroll its methodologies to address pressing environmental concerns around the world. Take, for example, the article by Manjusha Gupte and Robert V. Bartlett that appeared in this journal in 2007, which argued that the existence of deliberative institutions in rural India presents "significant challenges" to extant deliberative democratic theories. Entitled "Necessary Preconditions for Deliberative Environmental Democracy? Challenging the Modernity Bias of Current Theory," the authors argue against the accepted wisdom that "democratic deliberation is suited only to conditions

1. Latour $1993,10$.

Global Environmental Politics 9:4, November 2009

๑ 2009 by the Massachusetts Institute of Technology 
of advanced modernity." ${ }^{2}$ Empirical evidence of a functional village-level form of deliberative democracy in what they call "nonmodern" rural India enables Gupte and Bartlett's claim that conditions other than those of advanced modernity do allow for thriving deliberative democracy.

While sympathetic to their aims, this article argues that Gupte and Bartlett's claim - that deliberative democratic research is biased towards the Westunderstates the significance of the issues they touch upon. This article argues that rather than just being a case of bias, the concepts of modernity and the nonmodern are problematic and imprecise. For this reason, they are weak conceptual foundations for deliberative environmental democracy to continue to rest uncritically upon, as Gupte and Bartlett's analysis does. On one hand, the term modernity is often deployed as shorthand for "wealthy liberal democracies." ${ }^{3}$ Similarly "nonmodern" suggests social, economic and political conditions like those of the rural India of Gupte's and Barttlet's case study. Thus, as adjectives they can, to some degree, describe prevailing institutional and sociopolitical conditions.

On the other hand, the terms modern and nonmodern are nouns: according to Latour's quote above, proper nouns-i.e. the Modern and the Ancient. And as such, these nouns are used to encapsulate particular superior qualities and capacities of a certain group of people, like Latour's Moderns. These Moderns stand in distinction to those supposedly lacking such capacities, i.e. Latour's Ancients, who are deemed to be thoroughly steeped in tradition, primordial cultural practices, and bounded local knowledge. As such, this article argues that the assumptions and centrality of this binary of Ancients and Moderns (them/us, rational/irrational) in deliberative theory requires thorough and critical interrogation, which necessitates more than the redressing of a bias by adding nonmodern case studies to this body of work (as interesting and illuminating as these case studies are).

Such interrogation is undertaken in this article. It begins with conceptual discussions of the Modern and the Nonmodern in the next section. This is followed by an illustrative example of qualitative data from deliberative workshops into forest management options in northern New Mexico, USA. This is a place positioned within the supposed geographical hub of modernity, the United States. Yet, it is also one where deliberators' histories, emotions, traditions, and ethnicities become the mainstay of reasoned and open deliberation, which is not characteristic of the Modern according to deliberative theory. As such, this article makes the claim that the task of an unbiased deliberative environmental democracy is not to cast Nonmoderns in the same light as Moderns; i.e., that they too can be reasoned and rational. ${ }^{4}$ As the northern New Mexico

2. Gupte and Bartlett 2007, 94.

3. Gupte and Bartlett 2007, 94.

4. Sen 2005, particularly chapters 1 and 13 . 
example illustrates, the task is to show how deliberation amongst so-called moderns trades as much in cultural practices and local knowledge as the Nonmodern. Or, in the words of Bruno Latour, we (the Moderns) have never actually been modern. The implications of this argument for deliberative environmental democracy thus supports broadening its empirical ambit, and a reconsideration of what is deemed "authentic" deliberation, and questions who are regarded as "authentic" deliberators, opening up sites and modes of deliberation beyond the currently limited purview of deliberative democratic theory.

\section{The Pre-Conditions for Deliberative Democracy and the Realization of "the Dream of Enlightenment"}

Before the empirical discussion of northern New Mexico, it is vital to examine who and what allegedly constitutes the Modern and modernity-and its alleged opposite-within existing deliberative democratic debates. Here, the prerequisites deemed indispensible for functioning deliberative democratic institutions are key.

Within the theoretical literature, particular societal conditions are considered fundamental prerequisites for effective democratic deliberation. Although debates about their specific contours continue, such prerequisites represent measures of cultural, economic, and political equality, without which the free and fair deliberation central to democratic theory is unattainable. However, as deliberative practices now emerge from, and seek to address, a "burgeoning variety of perspectives, problems and possibilities" the field of environmental decision-making ${ }^{6}$ - the possibility and the necessity of meeting said prerequisites has become open to fresh debate. In short, questions remains as to whether such preconditions really are indispensible to democratic deliberation.

While such prerequisites remains a contentious intellectual sparring ground, Gupte and Bartlett draw out ones that appears repeatedly within the literature, which they summarize as "socioeconomic and political equality; (2) education or literacy; (3) cultural homogeneity; (4) a level of overall societal wealth above an unspecified threshold; (5) the social and cultural norms of modernity; and (6) institutional fragmentation and pluralism." 7 Such preconditions are of course ideals. There are few, if any, nations or regions that have, do, or will meet these conditions in full. What, then, do they signal and why are they so important? In response to this question, it is necessary to consider deliberative democracy's recent historical and intellectual genesis-but briefly, as this has been written about at considerable length elsewhere. ${ }^{8}$

The recent revival of interest in deliberative democratic theory arose

5. Stirling 2006, 95.

6. See Smith 2003; and Niemeyer 2004.

7. Gupte and Bartlett 2007, 97.

8. For example, Bohman 1996. 
amongst North American and European intellectuals from concern about the unrepresentative nature of modern liberal democracies and the implications of this status quo for addressing pressing environmental challenges. ${ }^{9}$ Inevitably, such a project drew foremost on the intellectual genealogies of its proponents: that is, European philosophical traditions of the past few centuries. As a result, Baber and Bartlett contend, "it is evident that deliberative democracy is (at least in part) an effort to realize more fully the dreams of the Enlightenment." 10

What such "dreams" entail remains contentious. However, they are often typified as "an intellectual coming of age" ${ }^{11}$ where the Medieval shroud of nonmodern feudalism, superstition and religion is supplanted by reason and systematic inquiry, which together bring new freedoms of thought and new spaces of association and interaction. As such, today's deliberative turn has a direct-if somewhat circuitous-lineage to such ideals, echoed in claims that "new deliberative spaces seek to replicate social relations in scientific and literary public spheres of the late 17th and early 18th centuries in England and France."12 These public spheres are upheld as spaces where the distorting effects of selfinterest and personal beliefs are replaced by "authentic deliberation." Authenticity here is attained through arguments framed by "natural reason" and rationality, ${ }^{13}$ which together are believed to make claims comprehensible to all-an outcome that would not occur if arguments were framed through personal experience, religious beliefs, superstition, or emotion. And so, claim democratic theorists, as one is free to speak, one must also be heard. Thus, Rawls for one emphasized the "duty of civility": a moral imperative that for each speaker there are listeners willing to heed and learn. ${ }^{14}$ And as such, the deliberating subject stands as an able and willing personification of the Enlightenment ideal: a Modern in the truest sense.

But are not these Moderns now living in a state of post-Enlightenment, according to some theorists? Perhaps, but such an argument does little to diminish the theoretical centrality of the reasoning subject. Instead, it alters the relationships such subjects have with knowledge, trust and institutions. ${ }^{15}$ For example, Ulrich Beck and Anthony Giddens-although their work differs on many fronts-both argue that a particular form of modern subject typifies postindustrial society. Beck's ${ }^{16}$ arguments begin with the notion of the "Risk Society." Here the hazards of industrialization have exceeded society's collective capacity to control them. Thus, everyone-no matter how rich, well-connected, or educated-is exposed to multiple "bads" such as pollution, climate change, and food safety scares. Such conditions cause traditional modes of trusting, knowing

\footnotetext{
9. As outlined by Dryzek 2000.

10. Baber and Bartlett 2005, 7.

11. Williams 1999, 1.

12. Davies and Burgess 2004, 349.

13. Baber and Barlett 2005, 3 .

14. See Habermas 2006.

15. See Beck, Giddens, and Lash 1994.

16. Beck 1992.
} 
and being (e.g. class belonging and trust in church and state) to break down, replaced by a reflexivity wherein greater freedom from collective norms gives rise to new forms of politics and new sites of individualization and reasoning.

Some deliberative theorists suggest this new reflexivity primes subjects for deliberative democracy, in that all can now rethink preferences and thus partake in deliberative democratic practices. ${ }^{17}$ Yet, critics of the Risk Society thesis argue that its "hyper-Enlightenment"18 assumptions ignore the endurance and revitalization of cultural practices and institutions. ${ }^{19}$ In this view, Fukuyama's "end of history" thesis ${ }^{20}$ now looks absurd in the face of militant religious groups and a profound loss of confidence that humanity can and will address the challenges of climate change. ${ }^{21}$ Thus, "it is possible we are on the cusp of a new era, one that puts some key and assumed features of modernity into reverse." 22

But are there not still places and peoples that remain relatively untouched by all of the above: the Nonmoderns or Ancients, in Latour's words? Some argue so, but that these places are not excluded from deliberative democratic practices. For example, Gupte and Barlett use the case study of Mendha-Lekha in the Eastern Maharashtra state of India to show how poor and illiterate communities can govern themselves through a "village deliberative democracy." Here, the village council is attended by the vast majority of local subsistence farmers, who spend one afternoon every week in deliberation over key community issues, in what is described as a transparent and consensus-oriented manner.

While Mendha-Lekha does meet some of the prerequisites described above, such as cultural homogeneity and relative economic equality, many others are absent, including literacy, wealth, and the "norms of modernity." Thus, Gupte and Bartlett contend, this example of deliberative democracy functioning where many theoretical prerequisites are absent shows that "deliberation could work well in traditional, nonmodern communities in developing countries." ${ }^{23}$

Outside the confines of deliberative democratic theory, that nonmodern contexts can be egalitarian and deliberative is of little surprise, especially to anthropologists and development practitioners who have detailed the diversities, successes and failures of human small-scale self-organization. ${ }^{24}$ The point here, therefore, is not to contest Gupte's and Bartlett's claims per se. Rather, it is to argue that their case study has more profound implications for deliberative democratic theories and empirical case studies than they suggest. That is, case studies such as Mendha-Lekha imply that effective deliberation does not rely on the presence and qualities of the Modern. Indeed, as this article claims, it can thus be argued that deliberative environmental democracy can dispense with the Modern and the long shadow s/he has cast over deliberative empiricism with-

17. For example, Dryzek 2000.

18. Szerszynski, Lash, and Wynne 1996; and Wynne 1996.

19. Bourdieu 2001.

20. See Fukuyama 1992.

21. Fukuyama 2006.

22. Rundle 2007, 130.

23. Gupte and Bartlett 2007, 104.

24. Cornwall and Coelho 2007. 
out losing sight of the import of deliberative democracy's purpose and aims. How then to conceptualize deliberation and the deliberator if both the categories of the Modern and the Nonmodern are to be relinquished? To explore this question, the next two sections of this article draw on empirical research into environmental deliberation in northern New Mexico, USA to argue that all deliberating subjects display qualities and capacities of both the Modern and the Nonmodern, and that the presence of the latter is vital to, rather than the distortion or failure of, effective deliberation.

\section{Modernity, Forestry, and Deliberation in Northern New Mexico}

In October 2006, two deliberative processes were held in Taos, northern New Mexico. This article draws on observations and qualitative analysis of these processes. ${ }^{25}$ These processes consisted of two three-day workshops that were part of a larger Forest Ecological Restoration Analysis (ForestERA) project. The first workshop was attended by 20-30 stakeholders (the numbers fluctuated over the three-day process). Participants came from state and local land management agencies, nongovernmental organizations, academia and local government. The second workshop followed on immediately afterwards and consisted of 11 lay participants (five female, six male) from within the study area who had responded to recruitment calls in the local media and were selected to attend with a view to achieving a reasonably representative occupational and geographical spread of participants from across the region.

The ForestERA project's overall aims were to collect and collate primary and secondary "best available data" on current ecological conditions in key study sites in the Southwest USA and to use this data as the foundations of public debate about future forest restoration options in this region. The study site in north-central New Mexico covered an area of six million acres and includes ecosystems of desert scrub and spruce-fir forests at elevations from 5000 to 13,000 feet. ${ }^{26}$ Data on conditions such as tree stand densities in this area were collected by the ForestERA team and subsequently translated using Geographic Information System (GIS) software into spatial representations of current and possible future forest conditions. This data then served as a key stimulus to debate in the workshops, helping to shape and direct deliberators' attention towards discussions about priorities for forest restoration.

There are a number of reasons why such deliberative workshops were considered by the ForestERA team as a pertinent methodology to address forest restoration in northern New Mexico. ${ }^{27}$ For one, the project team broadly conceived

25. The fieldwork on which this analysis is based was carried out under ethics rules in accordance with researchers' institutional ethics protocols. Participants were aware that the author was a researcher and gave consent for their contributions to the deliberative fora to be used in this research. Quotes below, where not specifically attributed, were taken directly from this fieldwork. The two specific names used to refer to interventions by specific people are pseudonyms.

26. For more information on the ForestERA project, see Sisk et al. 2006; and Sisk et al. 2005.

27. This team was made up of conservation biologists, GIS specialists, and political/social scientists, the latter of which defines my role in the research. 
of the project under the auspices of a "new public ecology." ${ }^{28}$ This is a mode of working that acknowledges the need for public input into ongoing sciencepolicy dialogues, as without the inclusion of diverse bodies of knowledge and greater public ownership of decisions, policies are more likely to fail. These concerns were particularly acute in this region, given the contentious history of forestry management and use in northern New Mexico to date.

New Mexico is the one of the poorest states in the US, with the northerncentral counties (which encompass Taos and the ForestERA study site) being the poorest part of the state. ${ }^{29}$ This marginalization is unevenly distributed among different ethnicities and economic classes today and reaches back centuries. Northern New Mexico from 1500 onwards witnessed the seizure of Native America Pueblo lands and peoples by incoming Spaniards. Over the next 150 years, these Hispanic settlers lost much of this land to Anglo settlers. The Treaty of Guadalupe Hidalgo, negotiated between the United States and Mexico in 1848 as the latter took control of the region, secured on paper Hispanic land rights but was for the most part not honored in practice. Such economic and cultural marginalization has been further compounded by local "zero cut" forestry policies, which have prevented the removal of forestry products and smallscale sustainable logging in the region-a mainstay of livelihood practices for centuries. $^{30}$

It is not far-fetched to argue that northern New Mexico does not meet the prerequisites of modernity as set out in deliberative democracy theory. Compared to the rest of the United States, it has relatively low levels of wealth, socioeconomic equality and literacy, as well as high cultural heterogeneity. While it does have institutional fragmentation and pluralism, at least in terms of forest management and land ownership, the dizzying array of agencies involved have proven to be counter-productive in the long term, prompting cultural and institutional clashes of policy and practice that have impacted directly on inhabitants' livelihoods. Yet, northern New Mexico does not fit neatly into the category of the Nonmodern, either. Inhabitants have access to many of the trappings of modernity such as representative democratic processes and advanced technology, as well as public education and local and national income-generating opportunities. Therefore, places like Taos appear to occupy a middle ground, a hybridization of modern and nonmodern societal conditions-a state of affairs which in turn begs the question as to the place of the modern deliberating subject in the Taos workshops.

To address this question, the remainder of this article focuses on how participants engaged in debate and the subsequent outcomes of deliberation. The aim is to argue that effective deliberation revolved around modes of communication that supposedly belong squarely to the sites and capacities of the

28. See Sisk et al. 2005.

29. Atencio 2004.

30. See Kosek 2004. 
nonmodern subject. Here culture, tradition and emotion were brought to the forefront of workshops debates, underscoring how specific identities and modes of communication deemed to belong to that of the Ancient within deliberative theory (i.e. in contrast to Enlightenment ideals) did not prevent participants from adopting and partaking in the procedures of deliberative democratic processes.

\section{Displacing the "Rhetorical Fulcrum" of ForestERA}

A key requirement for full and informed participation in the ForestERA workshops was that all were able and willing to engage with the ecological data presented through the GIS technology. To do this, participants had to follow a particular line of scientific reasoning-one which the deliberative democratic theoretical prerequisites of education and literacy would facilitate, and thus one which requires the figure of the Modern to be present and engaged. In the Taos workshops, the project teams' scientific data were used to stimulate participants' debates about which aspects of forestry management should take priority over others and why. Thus, the ability to understand and converse in the science of environmental management was a key to participants' contributions because, as Lee and Roth ${ }^{31}$ claim, "scientific competence" is "the most important rhetorical fulcrum around which natural resource decisions are made or by which they are justified."

Critics of the "deliberative turn" argue that such reliance on particular modes of knowledge and reasoning stymie inclusive debate, excluding those not schooled in distinct vocabularies and norms. For this always to be true, it would mean that other discourses and knowledges would have been thoroughly silenced or overridden during not only the Taos workshops, but also all other deliberative processes. That is, those not well-versed in the methodologies and technologies of ForestERA-Latour's "Ancients" - would be marginalized and overridden by the vanquishing Moderns.

On one hand, there is some evidence of this. Here the specter of Iris Marion Young's deliberator par excellence appears ${ }^{32}$-a being who (far from coincidentally) closely mirrors the capabilities and worldviews of deliberative theorists, which allegedly sets up conditions "under which deliberation is dominated by well-educated white males well versed in the niceties of rational argument." ${ }^{133}$ Indeed, in the ForestERA workshops it was the Anglo male participants who overtly claimed to be schooled in, and therefore comfortable with, the logic and vocabularies of the ForestERA approach. They were the participants who took to the workshop methodology quickest and with greatest gusto, evidenced by both the number and the confidence of interjections. These partic-

31. Lee and Roth 2006, 430 .

32. See Young 2000; and Kohn 2000.

33. Dryzek 2001, 659; see also Tewdwr-Jones and Allmendinger 1998. 
ipants were most likely to draw on figures and arguments from scientific literature to support their claims. Through these contributions, they led the initial debate in workshops along paths of their own choosing.

What then of the other participants and modes of relating to the ForestERA data, which work in different ways from the logic of scientific literacy? As the workshops progressed, talk of science and GIS was noticeably decentered as the "rhetorical fulcrum." And this is a pivotal point in this article's argument. One line of analysis could suggest that debate thus lapsed from reason and rationality (modern) to non-rationality (nonmodern), and therefore moved away from authentic deliberation. However, taking up lines of argument from critics of deliberative democratic theory, I want to suggest instead that a hybridity of experience, tradition and scientific knowledge came to the fore. Here, the cultural narratives of Native American and Hispanic injustices and historical longevity were central, producing definite effects on the trajectory and outcomes of the workshops. In short, the figure and norms of neither the Modern nor the Nonmodern captures in full the debates and identities that predominated in Taos. That is, the fact that we (including the northern New Mexico deliberators) have never been modern does not automatically mean that, by the process of elimination, we are nonmodern.

One of the key debates within the workshops focused on the designation and management of wilderness areas-in particular, whether the extraction of forest products and grazing of cattle should be allowed on such land in the region. The prevailing "no-cut" forestry policies have resulted in rising tree stand densities and, many argue, the demise of local livelihood practices, as well as rising likelihood of catastrophic fire events, themes echoed by workshop participants. For example, Sarah (an Anglo female in her mid-40s) repeatedly stated that the only way to execute realistic and valid ecological restoration was to take "everyone and everything" - buildings, inhabitants, vehicles and workers-off the land. This argument mirrors the pro-preservation and anti-development aesthetic of regional and national (predominantly Anglo) environmental groups, which collectively argue that humans be evacuated from all "green" spaces ${ }^{34}$ (a position backed up by long-standing scientific forest management research and practice).

Yet, the responses of workshop participants displaced this discourse, drawn as it was from an amalgamation of forestry science and Anglo environmental politics. This move was exemplified by Luis, a Hispanic lifelong resident of the region who countered Sarah's claims with what he called "cowboy common sense science." This discourse drew on place-based and historically embedded ideas of who knew about, belonged to, and thus was able to speak about the land, a position that pertained for the most part to Hispanic and Native American participants. For example, workshop participants drew on stories from centuries past to qualify their opinions about how livelihood access to the forests did and could sustain ecosystem and community health. This included 
stories about how the broad spacing of trees in the forest once allowed horsedrawn carriages to drive straight through, thanks to selective and sustainable felling practices that produced healthy and productive ecosystems where "the grass was up to horses' bellies." Other participants recalled times when it was possible to drink straight from local streams: a feat no longer feasible as the "over-stocked" lands have caused local water to take on a "brown tint."

Another (Anglo) participant backed Luis up. Drawing on specific figures he had gleaned from conservation biology literature, he claimed that 222 trees per acre was an ideal stand density, in stark contrast to the 2000 trees per acre at which some local forests currently stand. These figures were legitimized by ForestERA team members, who stated that 222 trees per acre was reasonable, based on "historical range of variation (HRV) data for tree stands." Luis' claims were further reinforced by other participants' personal experiences of the ecological benefits of small regular fires.

This line of dialogue continued throughout and saw the formation of coalitions around assertions such as Luis', which drew together personal and shared cultural experiences and scientific data and methodologies. These coalitions, however, were not of pure form. That is, they were characterized not by science (the Modern) meeting local experience (the Nonmodern) and finding commonalities, nor by local knowledge gaining legitimacy through its alignment with the "cognitive authority" of ForestERA. Rather, it was the specific articulation of different ways of knowing within this deliberative space that generated a local authority and "a space in which to assert attachment to, and make claims on, a particular place through knowledge and use of natural resources." 35

Indeed, as research into the social and environmental politics of this region has argued, it is not possible to separate the scientific discourses of tree stands and conservation biology from the cultural history of land use and ownership. Instead, "the environmental and racial discourses in the region are mutually constituted." ${ }^{36}$ Does this mean that reasoned debate is not possible in this context? Deliberative democrats argue that reasoned debate requires "reflection and the possibility that minds can be changed." 37 This outcome appears unlikely in settings such as the Taos workshops where "one's position is tied to one's identify." ${ }^{38}$ Yet, in the Taos workshops debate centered on stories of identity, ethnicity and belonging which did not preclude the existence of open and reasoned deliberation. Indeed, the discussion within the Taos workshops achieved some shared vision and ownership of potential ways forward for regional forest restoration, while drawing heavily on narratives of identity, emotion, and history. The aims of the workshops were to produce a set of collectively agreed upon restoration priorities mapped onto specific sites within the study area. The first workshop fulfilled these aims. The second workshop got

35. Waage 2001, 848.

36. Wilmsen 2007,237

37. Dryzek 2005, 229.

38. Dryzek 2005, 229. 
part way there, running out of time due to the extensive debate taking placedebate that did reach some shared sense of what was valued in the region and why.

For example, participants such as Luis were not well-versed in the language and worldview of conservation biology and GIS. Yet others recognized and responded to the cultural histories and authority of those participants' belonging to the region. For example, Sarah's claims that forest restoration should equate with pristine wilderness was based on her having recently spent four days tracking deer, when she witnessed first-hand the damage done by clearing and intensive land management. In response, Luis contended he had spent 65 years running cattle in the exact same place. Thus, he knew the land and understood that land more than she ever could. His claim drew claps and murmurs of support from around the room, thus underscoring the effect of seemingly "unauthentic" deliberation on participants.

\section{So if We Have Never Been Modern, What Now?}

The preceding discussion of northern New Mexico is a modest attempt to open further debate on how the modern/nonmodern binary so central to deliberative democratic theory precludes the observation that "The Enlightenment rational subject is not the only possibility for political subjectivity, but a historicallyconstructed convention that is laden with exclusions." ${ }^{39}$ What then is to be done about other political subjectivities, the panoply of human experience and identities currently excluded from the deliberative turn, in theory and often in practice? One could claim subjectivities such as Luis' reanimate the nonmodern subject. As such, the goal is to mold such individuals and collectivities into reasoned modern beings - a project that, arguably, many deliberative democrats favor. Or, one can broaden the subjectivities with which the deliberative turn engages. This latter option is favored by some critical social thinkers who have scrutinized the multiple modes of interactions in which deliberators trade, claiming that "Deliberation is not only a normative ideal but also a messy, socially embedded encounter in which a complex series of judgments are constantly negotiated around the knowledges, legitimacy and identities of all individuals involved." 40 The question then becomes how to frame theoretically and analyze these "messy encounters:" these "different identities and the different kinds of communication that accompany them." 41 One solution is to "allow in" modes of engagement and communication other than "rational-speak," such as humor and irony. Such assertions pertain as much to what is said, as to how ideas are communicated. For example, Jürgen Habermas has recently reworked earlier arguments, questioning the boundaries of what is considered "within reason." For example, he has made the case that faith-based arguments should

39. Enstad 1998, 775.

40. Davies and Burgess 2004, 352.

41. Dryzek 2001, 660. 
be allowed into the liberal democratic public sphere, as we "cannot know whether secular society would not otherwise cut itself off from key resources for the creation of meaning and identity." ${ }^{22}$ Thus, some deliberative democracy theorists have paid attention to identity-based modes of communication in deliberation-but, arguably, more as an add-on to the framework of authenticity and modernity than as a critique of it in entirety.

What happens to the figure of the Modern in this context? If all (or at least a diverse number of) forms of communication, knowledge and identity are to be let in, does this not take the deliberative turn down an atheoretical path; one that disallows coherent evaluation of process and outcomes and descends into a relativist normative and empirical free-for-all? Not necessarily, and to explain why, debates within social and political research about grounding theory in quotidian knowledge and practices are of use. ${ }^{43}$ Here, claims are made that "in trying to understand the ethical and political constitution of people, it is more important to attend to how they behave than how they think they should behave (or, especially, how theorists argue they should think and then behave)." 44 This line of argument suggests an emphasis on "practice theory" 45 - that is, "watching what happens, listening to what is said, asking questions" 46 as a means to access how individuals make sense of and "go on" in the everyday. Thus, the deliberative turn could do just that: observe deliberation in situ, across diverse contexts and issues, side-lining the imperative to pre-determine who, where and what counts as authentic deliberation.

One potential problem with this line of analysis is that it suggests relentless empiricism wherein case study after case study charts differences and diversities but finds little in the way of common ground. While there is merit in such a concern, a fundamental rethink of the place of the modern subject in deliberation does not automatically suggest this outcome. Here, the work of social theorists such as Bruno Latour and his claims that "We have never been modern" 47 are once again pertinent. As already outlined, Latour (and others) argue that the figure of the modern subject is a historically constituted ideal, not the description of a definite entity or reality. He makes such claims through detailed ethnographic work on the production of scientific knowledge, which leads him to argue that the supposedly universal and value-free knowledge of the modern subject does not come into existence separate from the contingencies of time, place and personality. Serendipity, preferences, beliefs and power struggles all play their part, in both their most mundane and profound manifestations. How then has the Modern taken centre-stage in the West's understanding of itself and, indeed, in the philosophical foundations of deliberative democracy? Latour's answer is the formation of what he calls the "Modern Constitu-

42. Habermas 2006, 10.

43. For example see Rankin 2003.

44. Ferguson 2004, 379.

45. Rankin 2003.

46. Hammersley and Atkinson 1995, 1.

47. Latour 1993. 
tion, ${ }^{\prime 4} 48$ a social order that arose in 17 th century Europe through public debate about the distribution of power between science and politics, and which resulted in the separation of the human world (politics) and the natural world (science) into still-existent domains of thought and practice. Yet, as Latour argues, in reality, how we come to know and act in the world cannot be separated out so neatly into distinct domains. Thus, the modern world has never happened, in the sense that it has never functioned according to the rules of its official Constitution alone." 49 While there is not space here to dwell on the specifics, Latour's work underscores one way in which the modern subject can and has been displaced as indispensible to deliberative environmental democracy. Such a move is more than just an exercise in intellectual pontification. It has a thoroughly political and applied impetus, as it eschews the narrative of the superior capacities of the Modern and looks to dismantle "the Great Divide, the great narrative of the West, set radically apart from all cultures." 50 This is not to argue away differences between peoples or, at the other extreme, to valorize difference as a good in and of itself. Rather, the aim here is to question how theoretically and empirically to treat and analyze such differences if the reification of abstract cultural forms and subjects is no longer taken as given-that is, if the Modern and the Nonmodern are no longer unproblematic nouns.

One perspective is to frame deliberative environmental democracy as the subject of ethnographic research. What might deliberative democracy as an ethnographic endeavor that fully embraces practice theory look like? To address this question, this article returns finally and in brief to the case study of Mendha-Lekha. Gupte and Bartlett state that this isolated and nonmodern community is not distinctive in its region of India in terms of its economic and social make-up. However, it is unusual in its self-rule ethos, which is attributed to its roots in the Gond system of tribal governance. This hints at a line of investigation that eschews holding up an isolated case study as emblematic of a nonmodern state of being. Rather, one pertinent question is how MendhaLekha came to be the way it is, and how it remains so. This requires paying particular attention to the historical and contemporary relations Mendha-Lekha is embedded within, as polities, villages and institutions-whether rural or urban-are the outcome of specific historical and contemporary conditions, further intensified by the fact that seemingly "remote" or "non-capitalist" rural spaces are no longer so due to "greater intensities of globalization processes and of global interconnections in some rural localities. ${ }^{\text {51 }}$ Indeed, to return briefly to the northern New Mexico example, focusing only on what was happening "in the room" may very well give rise to the argument that debate was not authentic or deliberative, as it drew on deeply held identity politics that belonged to only a few participants. However, placing these debates within what is happening and has happened "outside the room" leads to a greater understanding of how

48. Latour 2004.

49. Rankin 2003, 39 .

50. Latour 1993, 112; see also Said 1978.

51. Woods 2007, 491. 
collective regional identities (of both Anglos and non-Anglos) have been formed through the narratives and experiences of injustice and loss that became so central to the ForestERA workshops. ${ }^{52}$ In short, the debates within these workshops "make sense" within their specific context. Indeed, deliberation in Taos devoid of the central discourses of identity, race and belonging would have failed to address in any meaningful way the key issues at stake for the regions' residents.

Thus, given the above, is there any rationale for the continuation of the deliberative turn, if not to achieve authentic deliberation as understood within prevailing theory? As other social scientists have claimed, the possibility is now open for exploring and working towards deliberative environmental democracies without reliance upon the "Modern Constitution." Thus:

This refigures the aims of deliberative process, seeing them less as routes to consensus and more as processes through which actors may be able to immerse themselves in the worlds of others. Deliberation can be recast as part of the wider cooperative processes through which modernist political institutions may be open to confrontations by the potentially nondualist forms of reasoning. ${ }^{53}$

The outcomes of such an immersion in the worlds of others; how deliberation can confront these "modernist political institutions"; and what "nondualist forms of reasoning" look like are points for further debate and exploration, which, as this article has argued, together have the potential to confront a problematic schism between theory and practice within the deliberative turn.

\section{Concluding Remarks}

This article was stimulated by, and is in part a response to, Gupte and Bartlett's call for deliberative democratic theorists to engage with contexts and institutions outside the West. The aim has been to further their claims that incidents of deliberative democracy in Nonmodern contexts present a "significant challenge" to received deliberative theory. However, contrary to Gupte and Bartlett, this article has argued that the significance of this challenge pertains not only to the fact that forms of deliberative democratic governance exist outside of the West, and thus need to be brought into the deliberative fold, questioning the pertinence of deliberative democrats' theoretical preconditions along the way. Such cases of deliberation in action in rural India highlight the highly problematic nature of the categories of Modern and Nonmodern that Gupte and Bartlett still hold as central to their analysis. In short, through the discussion of the dynamics of deliberative workshops in northern New Mexico, along with the work of theorists such as Latour, the concept of the modern subject as a universal and noncontentious category-an untroublesome noun as well as adjective-has been argued as requiring further conceptual and empirical scrutiny. 
This argument does not signal a retreat from the normative and political aims of the deliberative turn. Although there are claims to the contrary, analysts critical of deliberative democracy theory take the persistence of inequality and the creation of more egalitarian forms of political practice as their starting point. The methods to challenge these inequalities include scrutinizing received discourses, a tradition upon which this article has drawn. ${ }^{54}$ Thus, language seemingly naturalized, universal and voided of its historical genesis-such as the Modern and the Nonmodern-becomes open to question through empirical exploration and genealogical discourse methodologies, as developed through the work of Michel Foucault..$^{55}$

On an applied level, the purpose of this approach is to bring previously excluded sites of deliberation and modes of communication into conversation with deliberative democratic conceptual debates, to attempt to bridge an apparent schism between the theory and realpolitik of deliberation. For example, engaging and building upon the cultural narratives and diverse identities expressed in the northern New Mexico workshops-rather than dismissing them as Nonmodern or closed to alteration-offered the Taos participants the opportunity to engage and open for discussion the discourses of injustice and loss that have shaped society "outside the room." As it turned out, the desired environmental outcomes (selective logging) were brought into alignment with desired social outcomes (sustainable livelihoods), suggesting that within specific contexts such engagements can lead to both positive ecological and societal decisions, not a trade-off between them or a shutting down of deliberative engagement.

Thus, reframing the deliberative turn as an ethnographic project opens up the possibilities of experimentation in the forms and sites of deliberation. This fact sits comfortably with Pragmatist-inspired theorists who argue that democracy is first and foremost a form of social inquiry, not the end in itself that must have pre-determined conditions before it can proceed. ${ }^{56}$ But for some deliberative democratic theorists and practitioners such assertions may be hard to swallow given an emphasis to date on meeting very specific internal conditions within deliberative spaces, as well as external societal preconditions. However, for those who can see the potential that deliberative democracy as an ethnographic project contains, the work has just begun, to establish an inclusive and empirically grounded base on which to take these arguments forward.

\section{References}

Atencio, Ernest. 2004. La Vida Floresta: Ecology, Justice, and Community-Based Forestry in Northern New Mexico. Santa Fe, NM: Sierra Club.

54. See for example Butler 1997; and Nelson 1999.

55. For example, see Foucault 2004.

56. See Bohman 2004. 
Baber, Walter F., and Robert V. Bartlett. 2005. Deliberative Environmental Politics: Democracy and Ecological Rationality. London: MIT Press.

Beck, Ulrich. 1992. Risk Society: Towards a New Modernity. London: Sage Publications.

Beck, Ulrich, Anthony Giddens, and Scott Lash, eds. 1994. Reflexive Modernization: Politics, Tradition and Aesthetics in the Modern Social Order. Cambridge, UK: Polity Press.

Bohman, James. 1996. Public Deliberation: Pluralism, Complexity, and Democracy. Cambridge, MA: MIT Press.

- 2004. Realizing Deliberative Democracy as a Mode of Inquiry: Pragmatism, Social Facts and Normative Theory. Journal of Speculative Philosophy 18 (1): 23-43.

Bourdieu, Pierre. 2001. Masculine Domination. Stanford, CA: Stanford University Press.

Butler, Judith. 1997. Excitable Speech: A Politics of the Performative. New York and London: Routledge.

Cornwall, Andrea, and Vera Schatten Coelho. 2007. Spaces for Change? The Politics of Citizen Participation in New Democratic Arenas. London: Zed Books.

Davies, Gail. 2006. The Sacred and the Profane: Biotechnology, Rationality, and Public Debate. Environment and Planning A 38 (3): 423-443.

Davies, Gail, and Jacquelin Burgess. 2004. Challenging the "View from Nowhere:" Citizen Reflections on Specialist Expertise in a Deliberative Process. Health and Place 10 (4): 349-361.

Dryzek, John. 2000. Deliberative Democracy and Beyond: Liberals, Critics, Contestations. Oxford: Oxford University Press.

. 2001. Legitimacy and Economy in Deliberative Democracy. Political Theory 29 (5): 651-669.

2005. Deliberative Democracy in Divided Societies: Alternatives to Agonism and Analgesia. Political Theory 33 (2): 218-242.

Duncan, J. S., and N. G. Duncan 2001. The Aestheticization of the Politics of Landscape Preservation. Annals of the Association of American Geographers 91 (2): 387-409.

Enstad, Nan. 1998. Fashioning Political Identities. American Quarterly 50 (4): 745-782.

Ferguson, Kennan. 2004. I • my Dog. Political Theory 32 (3): 373-395.

Foucault, M. 2004. Society must be Defended. London: Penguin.

Fukuyama, Francis. 1992. The End of History and the Last Man. New York: Free Press.

- 2006. After the Neocons: America at the Crossroads. London: Profile Books.

Gupte, Manjusha, and Robert V. Bartlett. 2007. Necessary Preconditions for Deliberative Environmental Democracy? Challenging the Modernity Basis of Current Theory. Global Environmental Politics 7 (3): 94-106.

Habermas, Jürgen. 2006. Religion in the Public Sphere. European Journal of Philosophy 14 (1): 1-25.

Hammersley, Martyn, and Paul Atkinson. 1995. Ethnography: Principles in Practice. London: Routledge.

Kohn, Margaret. 2000. Language, Power, and Persuasion: Towards a Critique of Deliberative Democracy. Constellations 7 (3): 408-429.

Kosek, Jake 2004. Deep Roots and Long Shadows: The Cultural Politics of Memory and Longing in Northern New Mexico. Environment and Planning D 22 (3): 329-354.

Latour, Bruno. 1993. We Have Never Been Modern. Cambridge, MA: Harvard University Press.

2004. Politics of Nature: How to Bring Science into Democracy. Cambridge, MA: Harvard University Press.

Lee, Stuart, and Wolff-Michael Roth 2006. Community-level Controversy over a Natural 
Resource: Toward a More Democratic Science in Society. Society and Natural Resources 19 (5): 429-445.

Nelson, Lise. 1999. Bodies (and Spaces) Do Matter: The Limits of Performativity. Gender, Place and Culture 6 (4): 331-353.

Niemeyer, Simon. 2004. Deliberation in the Wilderness: Displacing Symbolic Politics. Environmental Politics 13 (2): 347-372.

Rankin, Katharine. N. 2003. Anthropologies and Geographies of Globalization. Progress in Human Geography 27 (6): 708-734.

Rodriguez, S. 2001. Tourism, Whiteness and the Vanishing Anglo: Seeing and Being Seen. In Tourism in the American West, edited by D. M. Wrobel and P. T. Long, 194-222. Lawrence, KS: University of Kansas Press.

Rundle, Guy. 2007. It's Too Easy to Say "God Is Dead." In The Best Australian Essays of 2007, edited by Drusilla Modjeska, 129-138. Melbourne, VIC: Black Inc.

Said, Edward. 1978. Orientalism. London: Routledge.

Sen, Amartya. 2005. The Argumentative Indian: Writings on Indian History, Culture and Identity. New York: Farrar, Straus and Giroux.

Sisk, Thomas, D., John W. Prather, Haydee M. Hampton, Ethan N. Aumack, Yaguang Xu, and Brett G. Dickson 2006 Participatory Landscape Analysis to Guide Restoration of Ponderosa Pine Ecosystems in the American Southwest. Landscape and Urban Planning 78 (4): 300-310.

Sisk, Thomas, D., Melissa Savage, Donald A. Falk, Craig D. Allen, Esteban Muldavin, and Patrick McCarthy 2005. A Landscape Perspective for Forest Restoration. Journal of Forestry 103 (6): 319-320.

Smith, Graham 2003. Deliberative Democracy and the Environment. London: Routledge.

Stirling, Andrew. 2006. Analysis, Participation and Power; Justification and Closure in Participatory Multi-Criteria Analysis. Land Use Policy 23 (1): 95-107.

Szerszynski, Bronislaw, Scott Lash, and Brian Wynne. 1996. Introduction: Ecology, Realism and the Social Sciences. In Risk, Environment and Modernity: Towards a New Ecology, edited by Scott Lash, Bronislaw Szerszynski and Brian Wynne, 1-26. London: Sage.

Tewdwr-Jones, Mark, and Philip Allmendinger 1998. Deconstructing Communicative Rationality: A Critique of Habermasian Collaborative Planning. Environment and Planning A 30 (11): 1975-1989.

Waage, Sissel A. 2001. (Re)claiming Space and Place through Collaborative Planning in Rural Oregon. Political Geography 20 (7): 839-857.

Williams, David, ed. 1999. The Enlightenment: Cambridge Readings in the History of Political Thought. Cambridge: Cambridge University Press.

Wilmsen, C. 2007. Maintaining the Environmental-Racial Order in Northern New Mexico. Environment and Planning D 25 (2): 236-257.

Woods, Michael. 2007. Engaging the Global Countryside: Globalization, Hybridity and the Reconstitution of Rural Place. Progress in Human Geography 31 (4): 485-507.

Wynne, Brian. 1996. May the Sheep Safely Graze? A Reflexive View of the Expert-Lay Knowledge Divide. In Risk, Environment and Modernity: Towards a New Ecology, edited by Scott Lash, Bronislaw Szerszynski and Brian Wynne, 44-83. London: Sage.

Young, Iris Marion. 2000. Inclusion and Democracy. Oxford: Oxford University Press. 